\title{
Profil Protein Lima Jenis Daging yang Direndam Daun Pepaya Berbasis SDS-PAGE
}

\section{Five Types of Profile Meat Protein with Papaya Soaked Leaves Based SDS-PAGE}

\author{
A. Meryam Susanti ${ }^{*}$, Sri Darmawati ${ }^{2}$, Endang Tri Wahyuni Maharani ${ }^{3}$ \\ ${ }^{1}$ Magister Imunologi, Sekolah Pascasarjana, Universitas Airlangga \\ *email : andimeryamsusanti02@gmail.com \\ ${ }^{2}$ Laboratorium Biomolekuler, Fakultas Ilmu Keperawatan dan Kesehatan, \\ Universitas Muhammadiyah Semarang \\ ${ }^{3}$ Laboratorium Kimia, Fakultas Ilmu Keperawatan dan Kesehatan, \\ Universitas Muhammadiyah Semarang
}

\begin{abstract}
Meat is an important food for fulfill nutritional needs, many of meats are consumed as a source of highest quality nutrition for humans, especially as a source of protein. Papaya leaves contain the enzyme papain (a protase enzyme that can hydrolyze proteins), so that it can be used to soften meat. The purpose of this study was to look at an overview of protein profiles in five types of meat, namely goat, beef, buffalo, free-range chicken and broiler chicken which were soaked in papaya leaves. The protein profile of five types of meat was analyzed using the SDS-PAGE $12 \%$ method. The results showed that the control meat of goat, beef, buffalo, freerange chicken and broiler chicken which were not soaked in papaya leaves showed that there were many major protein bands compared to minor protein bands. Whereas in goat, beef, buffalo, free-range chicken and broiler chicken which have been soaked in papaya leaves, the results were different compared to the control, there were many minor protein bands. While the major bands only have 6 to 9 protein bands. Based on these results indicate that immersion with the enzyme papain contained in papaya leaves can break down peptide bonds, if it works on meat it can be broken down so the meat becomes tender and protein bands in the form of micromolecules.
\end{abstract}

Keywords; meat, papay leaves, protein profile, SDS-PAGE

\begin{abstract}
Abstrak
Daging merupakan bahan pangan yang penting dalam memenuhi kebutuhan gizi, banyak dikomsumsi sebagai sumber nutrisi yang berkualitas bagi manusia terutama sebagai sumber protein. Daun pepaya mengandung enzim papain (enzim protase yang dapat menghidrolisa protein), sehingga dapat digunakan untuk melunakkan daging. Tujuan penelitian ini untuk melihat gambaran profil protein pada lima jenis daging yaitu daging kambing, sapi, kerbau, ayam kampung dan ayam potong yang direndam daun pepaya. Profil protein lima macam daging dianalisis menggunakan metode SDS-PAGE $12 \%$. Hasil penelitian menunjukkan pada daging kontrol yaitu daging kambing, sapi, kerbau, ayam kampung dan ayam potong yang tidak direndam daun pepaya menunjukkan terdapat banyak pita protein mayor dibandingkan pita protein minor. Sedangkan pada daging kambing, sapi, kerbau, ayam kampung dan ayam potong yang telah direndam daun pepaya menunjukkan hasil yang berbeda dibandingkan dengan kontrol yaitu pada semua daging terdapat banyak pita protein minor. Sedangkan pita mayor hanya terdapat 6 sampai 9 pita protein saja. Berdasarkan hasil
\end{abstract}


tersebut menunjukkan bahwa perendaman dengan enzim papain yang terdapat dalam daun pepaya dapat memecah ikatan peptida, jika bekerja pada daging dapat diuraikan sehingga daging menjadi empuk, dan pita protein berbentuk mikromolekul.

Kata kunci; daging, daun pepaya, profil protein, SDS-PAGE

\section{PENDAHULUAN}

Salah satu zat gizi yang sangat dibutuhkan oleh tubuh adalah protein yang berfungsi sebagai zat pembangun dan pengatur. Protein juga berfungsi sebagai sumber energi jika karbohidrat dan lemak tidak tersedia lagi. Protein secara umum dibagi menjadi protein hewani dan protein nabati. Protein hewani lebih kompleks susunan asam aminonya dibanding dengan protein nabati (Bintang, 2010).

Protein merupakan suatu zat makanan yang sangat penting bagi tubuh, karena zat ini berfungsi sebagai bahan bakar dalam tubuh juga berfungsi sebagai zat pembangun dan pengatur. Protein merupakan makromolekul yang terbentuk dari asam amino yang tersusun dari atom nitrogen, karbon, hidrogen dan oksigen beberapa jenis asam amino yang mengandung sulfur (metionin, sistin dan sistein) yang dihubungkan oleh ikatan peptida (Budiyanto, 2002).

Selain kandungan proteinnya yang tinggi, daging merupakan produk hasil ternak yang banyak dikomsumsi sebagai sumber nutrisi yang berkualitas bagi manusia terutama sebagai sumber protein. Daging juga mengandung sejumlah senyawa lain seperi mineral Fe dan vitamin B yang sangat dibutuhkan oleh tubuh. Kualitas protein dapat dilihat dari komposisi asam amino penyusun dan daya cerna protein yang menentukan ketersediaan asam amino secara biologis. Salah satu komoditi peternakan yang merupakan sumber protein hewani dan sangat menunjang pemenuhan kebutuhan dasar bahan pangan di Indonesia adalah daging. Daging terbagi dalam dua jenis, yaitu daging ternak besar seperti sapi dan kerbau, maupun daging ternak kecil seperti domba, kambing dan babi (Soeparno. 2011).

Daging dapat diartikan sebagian jaringan otot dari hewan yang telah mengalami perubahan post-mortem, ada pula yang mendefinisikan bahwa daging merupakan sekumpulan otot dari karkas hewan. Karkas merupakan bagian tubuh ternak yang telah disembelih, dikuliti dan dihilangkan bagian isi perut serta kepala dan bagian dari kaki bawahnya. Daging merupakan bagian dari karkas namun tidak termasuk lemak (yang terdapat di bawah kulit maupun yang melindungi organ dalam), yang sering juga disebut dengan learn meat (Feiner, 2006).

Daging merupakan bahan pangan yang diperoleh dari hasil penyembelihan hewan-hewan ternak atau buruan. Hewan-hewan yang khusus diternakkan sebagai penghasil daging adalah berbagai spesies mamalia seperti sapi, kerbau, kambing, domba dan babi dan berbagai spesies unggas seperti ayam, kalkun dan bebek atau itik (Koswara, 2009). Banyak hal yang dapat mempengaruhi menurunnya kualitas daging, misalnya dengan pemanasan atau proses pada saat dimasak, temperatur yang begitu tinggi pada saat pemasakan dan lamanya waktu pemanasan maka semakin besar kadar cairan daging yang hilang. Perebusan daging pada suhu yang tinggi $\left(90^{\circ} \mathrm{C}\right)$ akan menyebabkan kerusakan jaringan episemum, perimysium dan endomesium, sehingga jaringan pada daging akan menyusut sekitar 30\%. Selain itu kandungan protein dalam daging dapat mengalami denaturasi (Lawrie, 2003).

Pelunakan daging dapat dilakukan dengan berbagai cara diantaranya dengan proses kimiawi. Secara kimiawi dapat dilakukan dengan dua cara yaitu dengan cara enzimatis dan non enzimatis. Secara enzimatis menggunakan enzim 
protease sedangkan non enzimatik menggunakan asam. Pemanfaatan asam ini sering dilakukan, baik di rumah maupun restoran, namun cara ini dapat mengurangi nilai gizi akibat protein yang terdenaturasi atau rusak oleh asam tersebut (Hidayah, 2013). Pelunakan daging secara enzimatis hingga saat ini belum banyak dilakukan, salah satu faktor penyebabnya adalah keterbatasan enzim dan juga keterbatasan referensi atas nilai gizi makanan yang diolah secara enzim. Salah satu cara untuk melunakkan daging yaitu menggunakan daun pepaya, selain dari daun pepaya bagian yang sering dimanfaatkan adalah buahnya, di masyarakat daun pepaya dimanfaatkan sebagai bahan makanan untuk dijadikan lalapan, bahan pelunak daging dan obat tradisional (Kamaruddin \& Salim, 2003).

Untuk memperbaiki kualitas daging maka perlu dilakukan pengolahan agar daging dapat menjadi empuk. Salah satu cara alami untuk mendapatkan kualitas daging yang empuk adalah dengan memanfaatkan enzim proteolitik atau protease untuk memecah ikatan-ikatan peptida dalam protein daging agar menjadi molekul-molekul yang lebih sederhana (Indrawan, 2015).

Dalam getah pepaya terkandung enzim-enzim protease (pengurai protein) yaitu papain dan kimopapain. Kedua enzim ini mempunyai kemampuan menguraikan ikatan-ikatan dalam molekul protein sehingga protein terurai menjadi polipeptida dan dipeptida. Jika bekerja pada daging dapat diuraikan sehingga daging menjadi empuk. Kedua enzim ini juga mempunyai daya tahan panas yang baik, bahkan proses pengempukan daging justru terjadi pada suhu pemasakan atau pada waktu daging dimasak, disamping pengurai protein, papain mempunyai kemampuan untuk membentuk protein baru atau senyawa yang menyerupai protein yang disebut plastein. Bahan pembentuk plastein berasal dari hasil peruraian protein daging (Hidayah, 2013).

Berdasarkan penelitian yang dilakuka Saputro (2015) menunjukan bahwa penambahan enzim papain yang didapatkan dari daun papaya dapat meningkatkan keempukan (daya tarik dan daya putus), $\mathrm{pH}$, daya ikat air dan menurunkan susut masak daging sapi. Untuk mengetahui karakteristik profil protein daging yaitu dengan menggunakan metode SDS PAGE, salah satunya adalah elektroforesis SDS gel poliakrilamida. Elektroforesis adalah suatu cara untuk memisahkan fraksi-fraksi suatu campuran berdasarkan atas pergerakan partikel koloid yang bermuatan di bawah pengaruh medan listrik. Cara elektroforesis telah digunakan untuk analisa virus, asam nukleat, enzim dan protein lain, serta molekul-molekul organik dengan berat molekul rendah seperti asam amino (Westermier, 2005).

Salah satu jenis elektroforesis yang digunakan secara luas pada saat ini adalah elektroforesis SDS gel poliakrilamida (SDS PAGE). SDS PAGE dinilai lebih menguntungkan dibandingkan dengan elektroforesis kertas dan elektroforesis pati. Hal ini disebabkan karena besarnya pori medium penyangga, serta perbandingan konsentrasi akrilamida dan bis-metilen akrilamida. Selain itu, gel ini tidak menimbulkan konveksi dan bersifat transparan (Bintang, 2010). Penelitian ini bertujuan untuk mengetahui gambaran profil protein pada lima jenis daging yang direndam daun pepaya.

\section{METODE}

Penelitian ini bersifat deskriptif, penelitian dilakukan di laboratorium Bioteknologi Universitas Gajah Mada dan Laboratorium Kimia Universitas Muhammadiyah Semarang pada bulan Juni - Juli 2017. Variabel penelitian adalah daging, daun papaya, dan profil protein daging. Daging merupakan bagian tubuh dari hewan yang diperoleh dari hasil penyembelihan. Daun papaya adalah bagian dari tanaman pepaya yang dihaluskan dan mengandung enzim papain. Profil protein daging adalah profil sub-sub unit protein yang menyusun 
protein pada daging yang diperoleh dengan metode SDS-PAGE. Objek penelitian ini adalah lima macam sampel daging (kerbau, kambing, ayam potong, ayam kampung, sapi) pada tiap sampel daging direndam daun papaya selama 20 menit. Kemudian dihaluskan dan dicentrifuge untuk mendapatkan supernatan selanjutnya dilakukan separasi dengan SDS-PAGE pada tiap sampel untuk mengetahui profil protein.

\section{HASIL DAN PEMBAHASAN}

Sampel yang digunakan dalam penelitian ini adalah daging sapi, kambing, kerbau, ayam kampung, ayam potong yang masih segar tanpa formalin yang direndam daun papaya dengan konsentrasi $100 \%$ selama 20 menit. Total protein daging sapi, kambing, kerbau, ayam kampung, ayam potong dianalisa menggunakan spektrofotometer.

Tabel 1. Total Protein Daging Sebelum dan Sesudah Perendaman Daun Papaya

\begin{tabular}{lcc}
\hline \multirow{2}{*}{ Jenis Daging } & \multicolumn{2}{c}{ Total Protein $(\mu \mathrm{g} / \mu \mathrm{l})$} \\
\cline { 2 - 3 } & $\begin{array}{c}\text { Sebelum } \\
\text { Perendaman }\end{array}$ & Setelah Perendaman \\
\hline Kambing & 7,39 & 5,82 \\
Sapi & 6,74 & 5,67 \\
Kerbau & 5,30 & 4,98 \\
Ayam kampung & 10,31 & 8,59 \\
Ayam potong & 15,64 & 14,82 \\
\hline
\end{tabular}

Berdasarkan Gambar 1 dan 2 didapatkan jumlah pita mayor dan pita minor yang tertera pada Tabel 2.

Tabel 2. Jumlah Pita Mayor dan Pita Minor pada Sampel Daging

\begin{tabular}{ccc}
\hline \multirow{2}{*}{ Sampel } & \multicolumn{2}{c}{ Pita } \\
\cline { 2 - 3 } & Mayor & Minor \\
\hline Ka.C & 14 & 5 \\
Ka.R & 7 & 12 \\
Sa.C & 11 & 7 \\
Sa.R & 9 & 13 \\
Ke.C & 11 & 7 \\
Ke.R & 12 & 12 \\
Ak.C & 7 & 6 \\
Ak.R & 8 & 13 \\
Ap.C & 8 & 6 \\
Ap.R & 9 & 14 \\
\hline
\end{tabular}

Daging yang sudah direndam daun pepaya diisolasi protein dengan metode Laemmli (1970) kemudian diseparasi dengan SDS PAGE 12\% dan diwarnai dengan 0,1\% Coomasie Brilliant Blue (CBB) R-250 selama 30-60 menit pada suhu ruangan hingga pita protein terwarnai. Menurut Muchtaromah et al (2012) penentuan berat molekul $(\mathrm{BM})$ protein dilakukan dengan menghitung $\mathrm{Rf}$ (Retardation Factor) dari masing-masing pita (band) protein dengan rumus sebagai berikut :

$$
\mathrm{Rf}=\frac{\text { Jarak pergerakan protein dari tempat awal }}{\text { Jarak pergerakan warna dari tempat awal }}
$$

Berat molekul (BM) dan nilai Retardation Factor (Rf) marker diplotkan pada kertas logaritma sehingga didapatkan BM sampel yang tertera pada Tabel 3. 
Dari hasil spektofotometer daging kontrol (sebelum perendaman) memiliki total protein yang lebih besar dibandingkan dengan daging yang direndam daun papaya. Total protein yang tertinggi adalah daging ayam potong sebesar 15,64 $\mu \mathrm{g} / \mu \mathrm{l}$, dan terendah adalah daging kerbau sebesar 5,30 $\mu \mathrm{g} / \mu \mathrm{l}$. Sedangkan daging yang telah direndam daun papaya memiliki total protein yang lebih rendah dibandingkan daging kontrol. Penambahan ekstrak daun papaya pada setiap sampel daging mempengaruhi total protein. Analisa profil protein dilakukan dengan metode SDS-PAGE terhadap daging yang direndam daun papaya selama 20 menit. Hasil tertera pada Gambar 1 dan 2 dibawah ini:
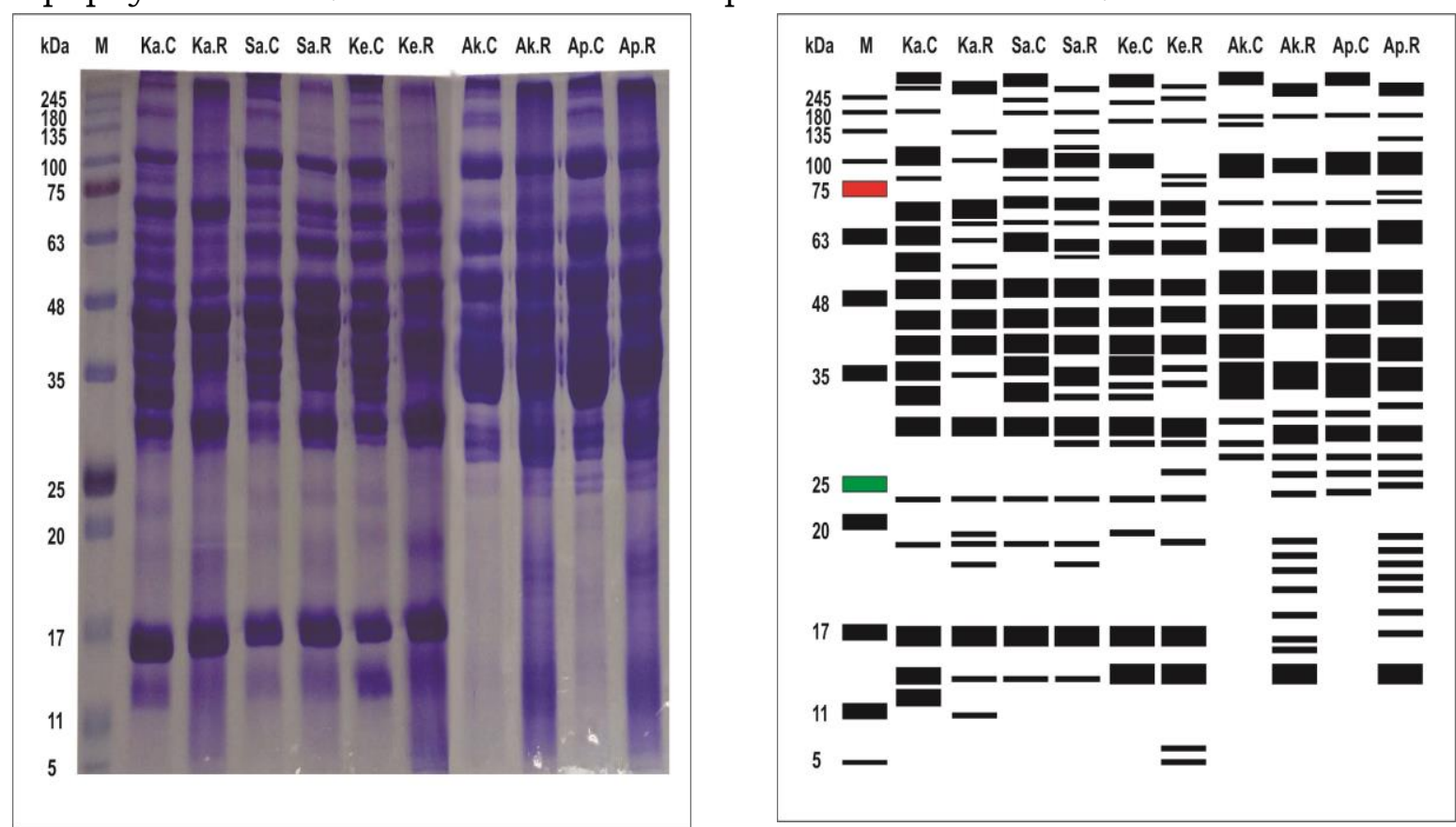

Gambar 1. Hasil Elektroforesis SDS-PAGE

Gambar 2. Hasil Visualisasi

Keterangan :

M : Marker

Ka.C : Kambing kontrol

Ka.R : Kambing rendam

Sa.C : Sapi kontrol

Sa.R : Sapi rendam
Ke.C : Kerbau kontrol

Ke.R : Kerbau rendam

Ak.C : Ayam kampung kontrol

Ak.R : Ayam kampung rendam

Ap.C : Ayam potong kontrol 
Tabel 3. Berat Molekul (BM) Protein Daging

\begin{tabular}{ll}
\hline Sampel & Berat Molekul (kDa) \\
\hline Ka.C & $245,180,135,115,93,75,66,59$, \\
& 49, \\
Ka.R & $45,39,35,3224,20,17,13,12,245135,10$ \\
& $0,79,75,67,63,59,49,39,34,32,24,21,2$ \\
& $0,19,17,14,11$ \\
Sa.C & $245,180,135,115,93,75,71,59,49,39,3$ \\
& $5,32,24,20,17,13$ \\
Sa.R & $245,180,145,135,115,93,75,67$, \\
& $66,59,49,45,41,37,35,34,24,20$, \\
& $19,17,13$ \\
Ke.C & $245,145,135,93,75,67,59,57,4945,41$, \\
& $37,35,34,20,19,17,15$ \\
Ke.R & $245,145,115,67,66,59,57,53,4844,39$, \\
& $37,34,32,30,20,19,17,14$, \\
& 12,5 \\
Ak.C & $245,100,79,63,58,49,42,37,34,31,29,2$ \\
& 7,25 \\
Ak.R & $135,100,63,58,49,42,37,31,26,25,23,2$ \\
& $0,19,18,17,16,15,14$ \\
Ap.C & $245,100,79,58,49,42,37,34,31,26,25,2$ \\
& 3,20 \\
Ap.R & $135,100,70,63,62,58,49,42,37,34,31,2$ \\
& $6,25,23,21,19,18,17,16,14,13$ \\
\hline
\end{tabular}

Protein merupakan senyawa nutrisi utama yang terdapat dalam daging. Setiap pensekresian molekul DNA yang terdapat dalam sel akan menghasilkan protein (Ikmalia, 2008). Menurut Feiner (2006), daging dapat diartikan sebagai jaringan otot dari hewan yang telah mengalami perubahan post-mortem. Menurut Nani (2007) papain dapat bermanfaat dalam rumah tangga seperti untuk melunakkan daging. Salah satunya adalah getah yang terdapat pada daun papaya dapat memecah ikatan peptida menjadi molekul-molekul protein yang lebih sederhana sehingga dapat melunakkan daging (Kurniawan, 2014). Papaian juga dapat digunakan sebagai pencerna protein dan diberikan sebagai topical untuk debridemen enzimatik. Pita protein pada gel terbentuk oleh pengaruh separasi protein. Aliran listrik mempengaruhi molekul protein bermigrasi dari kutub negatif menuju kutub positif dan molekul protein tersebut bermigrasi berdasarkan berat molekul dan tingkat migrasi dalam medan listrik (Bintang, 2010).

\section{PENUTUP}

Berdasarkan hasil tersebut menunjukkan bahwa perendaman dengan enzim papain yang terdapat dalam daun pepaya dapat memecah ikatan peptida, jika bekerja pada daging dapat diuraikan sehingga daging menjadi empuk dan pita protein berbentuk mikromolekul. Disarankan untuk melakukan penelitian lanjutan dengan lama waktu perendaman agar pita protein dapat terurai dengan baik. Dengan menggunakan enzim papain yang berasal dari bagian pepaya yang lain, yang masih mengandung enzim papain, yaitu buah dan batang. 


\section{DAFTAR PUSTAKA}

Bintang M. 2010. Biokimia Teknik Penelitian .Erlangga. Jakarta.

Budiyanto M. 2002. Gizi dan kesehatan.Bayu Media dan UMM Malang. Malang.

Feiner G. 2006. Mead Products Handbook; Protical Science and Tekhnologi. Woodhead Publishing Limited Cambridge.

Hidayah L. 2013. Uji Aktifitas Enzim Bromalin dan Uji Enzim Papain. Jurusan Peternakan Negri Jember.

Ikmalia. 2008. Analisa Profil Protein Isolat Excherichia Coli SI Hasil Dari Iradiasi Sinar Gamma. Universitas Islam Negri Syariff Hidayatullah. Jakarta.

Indrawan I. 2015. Enzim Pengempuk Daging.http://bakrie.ac.id/id/beritaitp/artikel-pangan/913-enzim pengempuk-daging. [diakses tanggal 20 April 2017].

Koswara S. 2009. Teknologi Praktis Pengolahan Daging. E-book Pangan.

Kamaruddin M \& Salim. 2003. Pengaruh Pemberian Air Perasan Daun Pepaya pada Ayam : Respon Patofisiologik Hepar. Jurnal Sain Veterinet. 20(1). 37 34.

Kurniawan RF. 2014. Rahasia Terbaru Kedahsyatan Terapi Enzim. Healthy Books. Jakarta.

Lawrie RA. 2003. Ilmu Daging Ed ke 5. UI-Press. Jakarta.

Nani. 2007. Potensi Pasar Papain Sangat Besar. http//ikm.Kemenperin.go.id. [diakses tanggal 08 April 2017].

Saputro TA. 2015. Profil Protein Daging Sapi yang Direndam Daun Pepaya. [Skripsi]. Universitas Muhammadiyah Semarang. Semarang.

Soeparno. 2011. Ilmu Nutrisi dan Gizi Daging. UGM Press. Yogyakarta.

Westeimer R. 2005. Electrophoresis in Practice : A Guide to Methods and Aplication of DNA and Protein Separations. John Wiley \& Sons inc. NewJersey. 